\title{
Investigative Study on Emissions Level and Cost Analysis of Diesel Powered and Solar PV-Diesel Hybrid Systems
}

\author{
Olusegun Olufemi Ajide, Chioma Irene Eze, Temilola Taiwo Olugasa*, Olawale Saheed Ismail \\ Department of Mechanical Engineering, University of Ibadan, Ibadan, Oyo State, Nigeria \\ Email: ^temilola18@yahoo.co.uk, *tt.olugasa@ui.edu.ng
}

How to cite this paper: Ajide, O.O., Eze, C.I., Olugasa, T.T. and Ismail, O.S. (2021) Investigative Study on Emissions Level and Cost Analysis of Diesel Powered and Solar PV-Diesel Hybrid Systems. World Journal of Engineering and Technology, 9, 516-526. https://doi.org/10.4236/wjet.2021.93034

Received: April 26, 2021

Accepted: July 27, 2021

Published: July 30, 2021

Copyright $\odot 2021$ by author(s) and Scientific Research Publishing Inc. This work is licensed under the Creative Commons Attribution-NonCommercial International License (CC BY-NC 4.0).

http://creativecommons.org/licenses/by-nc/4.0/

\begin{abstract}
In this work, a comparative study on emissions and cost implications of diesel powered and solar photovoltaic-diesel hybrid systems was carried out for three commercial banks. With the aid of HOMER Pro software, meteorological data, energy demand, system component data, capital and operating costs were used for analysis of the two systems. The results showed that in Bank A, the diesel generator alone releases $111,618 \mathrm{~kg} / \mathrm{yr}$ of Carbon dioxide while the hybrid system releases $41,618 \mathrm{~kg} / \mathrm{yr}$ of Carbon dioxide. For Bank B the quantity of carbon dioxide emissions released from the diesel generator in Bank B is $53,830 \mathrm{~kg} / \mathrm{yr}$, while the carbon dioxide released from the hybrid energy system is $24,082 \mathrm{~kg} / \mathrm{yr}$. For Bank C, the diesel generator alone released 177,799 $\mathrm{kg} / \mathrm{yr}$ of Carbon dioxide and 129,060 kg/yr of carbon dioxide was released from the hybrid system. This suggests that the diesel generator alone releases more emissions when compared with the hybrid system in all the three banks. The Net present cost of energy and levelized cost of energy were used to find out the cost effectiveness of hybrid systems. The results showed that the levelized cost of energy for the generator alone and hybrid system, respectively in Bank A is $\$ 0.713$ and $\$ 0.343$. While for Bank B, it is $\$ 0.568$ and $\$ 0.2553$. Finally for Bank $C$, it was $\$ 0.731$ and $\$ 0.556$. Therefore, solar-diesel hybrid system has a comparatively low emission and can be considered as a more economical option for electricity generation.
\end{abstract}

\section{Keywords}

Hybrid System, HOMER Pro, Levelized Cost of Energy

\section{Introduction}

Energy is indispensable for the economic and social development of a nation [1] 
and it helps improve the quality of life. Several studies have shown that there is a strong connection between energy consumption and economic growth. Availability of energy therefore, directly contributes to economic growth and poverty reduction of a country through creation of wealth [2] \& [3]. The poor state of power in Nigeria has been seen as one of the major impediments to economic growth [4]. Globally, the demand for energy is increasing at a geometric rate and it is projected that it will have a 55\% increase from 2013 to 2035 [5]. The growing researcher's interests for provision of energy solution in a reliable, efficient and environmentally friendly manner such that climate change can be mitigated [6] [7] [8] and [9] can help stimulate economic growth. This growth cannot be sustained by the conventional energy sources which are dependent on the fast depleting fossil fuels. Apart from their non-renewability, the use of fossil fuels as source of energy causes several negative environmental impacts such as the emissions of greenhouse gases, which pollutes the atmosphere and contribute to global warming [10] and [11].

Renewable energy sources such as solar energy, wind power, biofuels, in recent times are viewed as the future energy solution to the depleting fossil fuels as well as the environmental degradation associated with the use of fossil fuels. Renewable energy sources are being utilised either in on-grid or off-grid applications. However, the limitation of renewable energy sources like solar energy and wind energy is dependence on climatic conditions which could affect its availability at certain times. There is therefore the need to combine renewable energy sources with conventional sources. The conventional energy sources are then able to augment the renewable energy sources when energy is not available from them or when energy demand is higher than that which can be met by the renewable energy sources. Such combination systems are known as Hybrid Energy Systems. Hybrid Energy Systems (HES) is a combination of two or more energy conversion devices to meet a common energy end use [12]. Various options exist for energy integration in hybrid systems. For instance, there could be the combination of renewable energy sources and conventional energy sources. A typical example is the diesel generator, a photovoltaic system and a battery system. In remote applications, solar, diesel generators and wind turbines are often used [12]. Hybrid energy systems are still an evolving technology with limited application areas and high costs. As more researches are conducted in this field of study, it is expected that there will be more standardised designs that will make it easy to size HESs as well as bringing about more synergy among the components of the hybrid system [13]. Hybrid systems are commonly sized through modelling. This reduces the cost significantly because there is optimum resource allocation which is based on load demand and renewable resource forecasting. According to Peterson et al. [14] about 35\% of the energy generated in HES is lost due to nonoptimised sizing of the system. HES could be utilised in grid connected mode or isolated mode. The isolated HESs offers a sustainable option for electrification of remote locations [12]. 
Solar energy has received special attention among the various types of renewable energy because it is freely available, abundant and renewable [15]. According to Bolaji and Adu [16], solar energy is the driving force behind several of the renewable forms of energy. The photovoltaic system has very simple configuration. It has four main components: photovoltaic modules to convert sunlight into electrical energy; battery to store and deliver electrical energy in usable form; charge controller to regulate level of charging to and from the battery; and appliances such as lamps, computers, d.c. motor driven devices and telecommunication equipment. Optimisation of HESs can be done using sizing software which evaluates the overall behaviour of the system. Examples of popular ones are: Hybrid2 developed by Centre for Energy Efficiency and Renewable Energy (CEERE), Hybrid Optimisation Model for Electric Renewable (HOMER) which was developed by National Renewable Energy Laboratory (NREL) and Remote Area Power Supply Simulator (RAPSIM) which is a free and open source micro-network simulator [17]. Khare et al. [18] modelled the HES of Sagar, India using HOMER software. The meteorological solar insolation data and hourly wind speeds were considered. Kamel and Dahl [19] also used HOMER software to estimate the optimum component size that can be achieved at the lowest cost for a stand-alone hybrid energy system. Genetic Algorithm (AG) optimization technique is also used for optimization of HES. Nafeh [20] used this AG technique to size a PV-wind hybrid system and obtained results that showed that the PV-wind hybrid lowers system cost compared to cases where either PV-alone or windalone systems were used.

The focus of this study is to examine carbon emissions level and cost analysis of two electricity generation sources using HOMER Pro software. Attempt was made to compare the quantity of emissions produced from a diesel generator and a hybrid solar photovoltaic-diesel generator system. In addition, a comparative evaluation of the cost effectiveness of a hybrid energy system and a standalone diesel system, was carried out.

\section{Methodology}

Data for the components were acquired from the management of the three banks. The data includes the system configuration of the installed power system, hourly electrical variation, and electrical generation data of the solar and diesel generation system. The lifetime of the entire project was taken to be 25 years. The data collected served as input data for carrying out simulation with HOMER Pro. HOMER Pro was used to select feasible hybrid solutions as a feasible system is defined as a solution or hybrid system configuration that is capable of meeting the load.

\subsection{Background of Study Area}

The five study areas are located in Lagos, Nigeria. Lagos is a metropolitan city in Nigeria. It is the most populous city in Nigeria and Africa. It is also one of the 
fastest growing cities in the world. It has a population of about 16 million people. The landmass is 385.9 sq mi. Lagos is currently the commercial hub of Nigeria as it contains several industries and business districts and there is high demand for energy to carry out important activities. This study was carried out in three banks in Lagos with coordinates of 4.9338706, 6.2834823, 9.0671758, 7.4628352 and $6.4382629,7.4802774$.

\subsection{Meteorological Data}

Global Horizontal Irradiance (GHI) is the total solar radiation incident on a horizontal surface. It is the sum of Direct Normal Irradiance (DNI), Diffuse Horizontal Irradiance, and ground-reflected radiation. HOMER uses Solar GHI to compute flat-panel PV output. The data in Table 1 shows a moderately high solar insolation with the annual average GHI given as $4.76 \mathrm{kWh} / \mathrm{m}^{2}$ hence harnessing solar energy through the deployment of Renewable Energy Technology (RET) would appear feasible. Table 1 shows the monthly GHI for the location. The monthly clearness index and radiation is shown in Table 1 . The data was compiled by HOMER Pro database as it retrieves the information concerning each region from NASA.

The temperature resource data was also retrieved from NASA surface meteorology and solar resource Database. From Figure 1, it was observed that April had the highest daily temperature and August had the lowest temperature. The annual average temperature is given as $25.75^{\circ} \mathrm{C}$. Figure 1 shows the average daily temperature.

\subsection{Energy Demand Analysis}

The daily energy consumption was obtained with an energy logger. This gives accurate data on the daily energy consumption compared to checking appliances

Table 1. Solar radiation data.

\begin{tabular}{ccc}
\hline Month & Clearness Index & Daily Radiation $\left(\mathrm{KWh} / \mathrm{m}^{2} /\right.$ day $)$ \\
\hline Jan & 0.530 & 4.935 \\
Feb & 0.523 & 5.163 \\
Mar & 0.509 & 5.273 \\
Apr & 0.495 & 5.172 \\
May & 0.477 & 4.861 \\
Jun & 0.388 & 4.459 \\
Jul & 0.384 & 3.397 \\
Aug & 0.411 & 3.590 \\
Sep & 0.411 & 4.240 \\
Oct & 0.501 & 4.997 \\
Nov & 0.565 & 5.318 \\
Dec & 0.536 & 4.876 \\
\hline
\end{tabular}


and their power rating. Bank A operates for 12 hours in the day and has a daily total energy consumption of $174 \mathrm{kWh} /$ day. Bank B operates for 11 hours and has total energy consumption of $108 \mathrm{kWh}$ /day while bank C operates for 12.5 hours with total energy consumption of $333.6 \mathrm{kWh} /$ day. Figures 2-4 shows the energy use pattern for each hour of the day indicating the peak load.

\subsection{System Components}

The hybrid system consists of a solar photovoltaic cell, diesel generator, battery

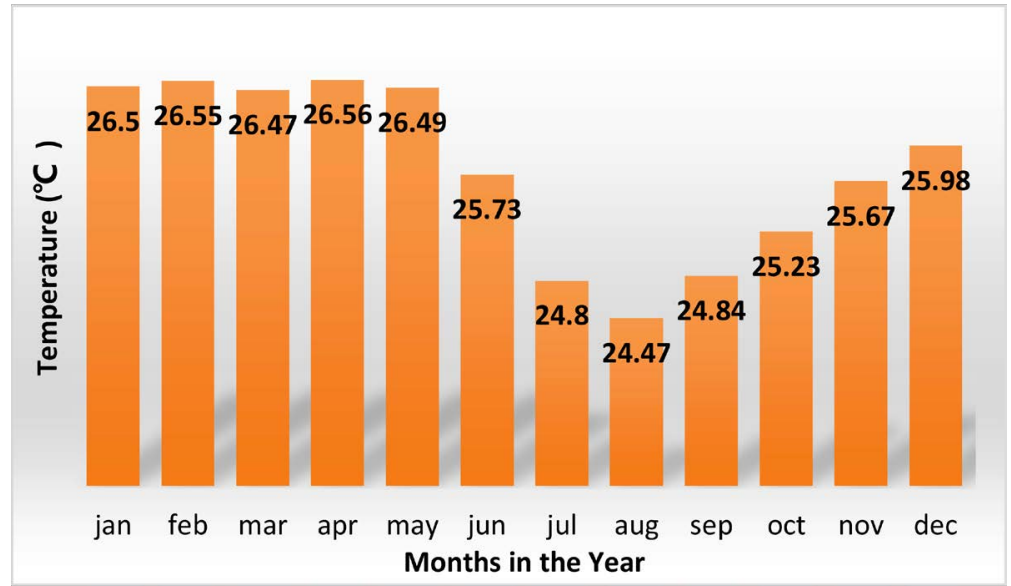

Figure 1. Average daily temperature for each month.

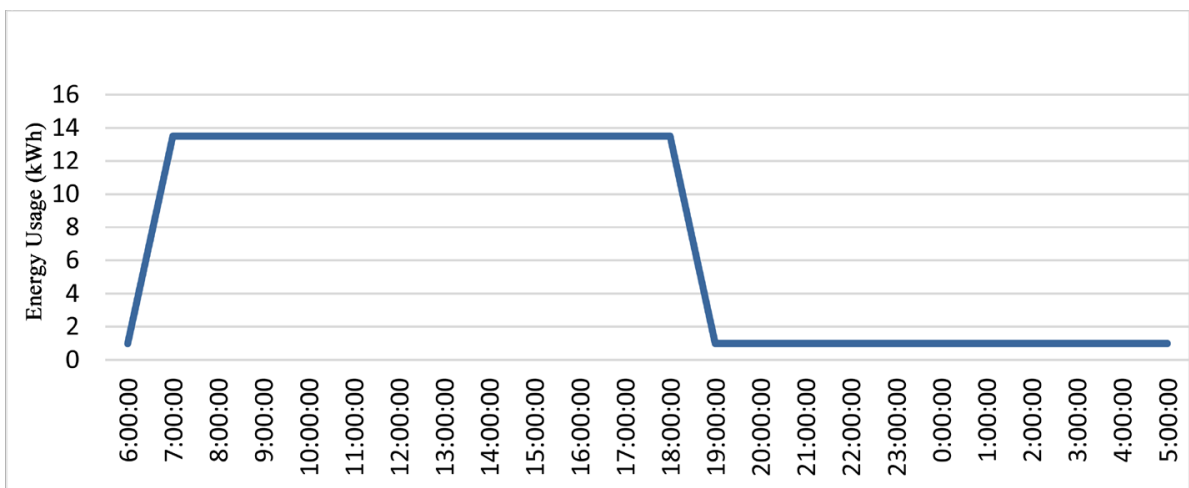

Figure 2. Energy use pattern for bank A.

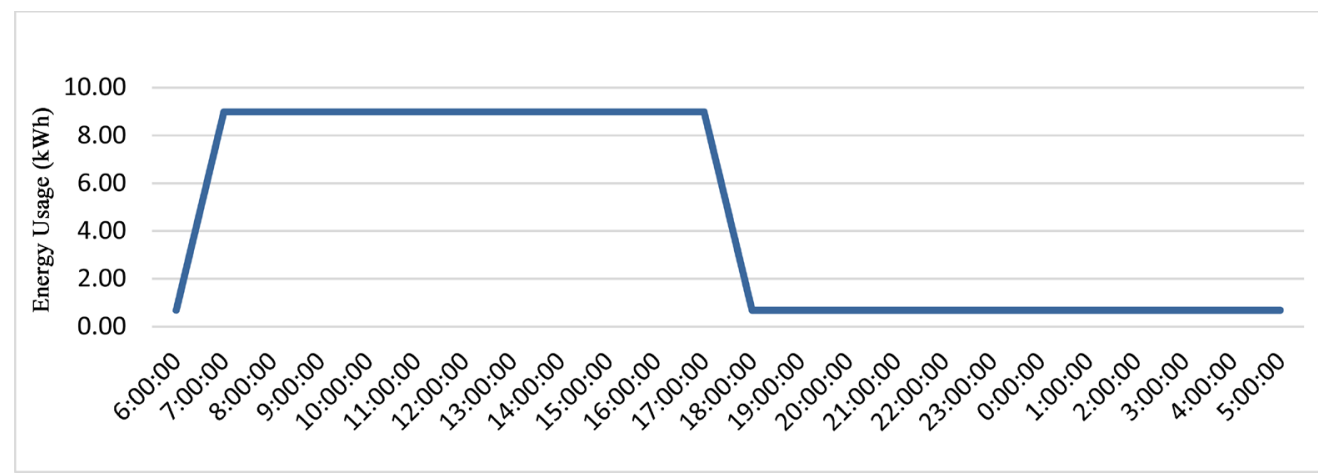

Figure 3. Energy use pattern for bank B. 


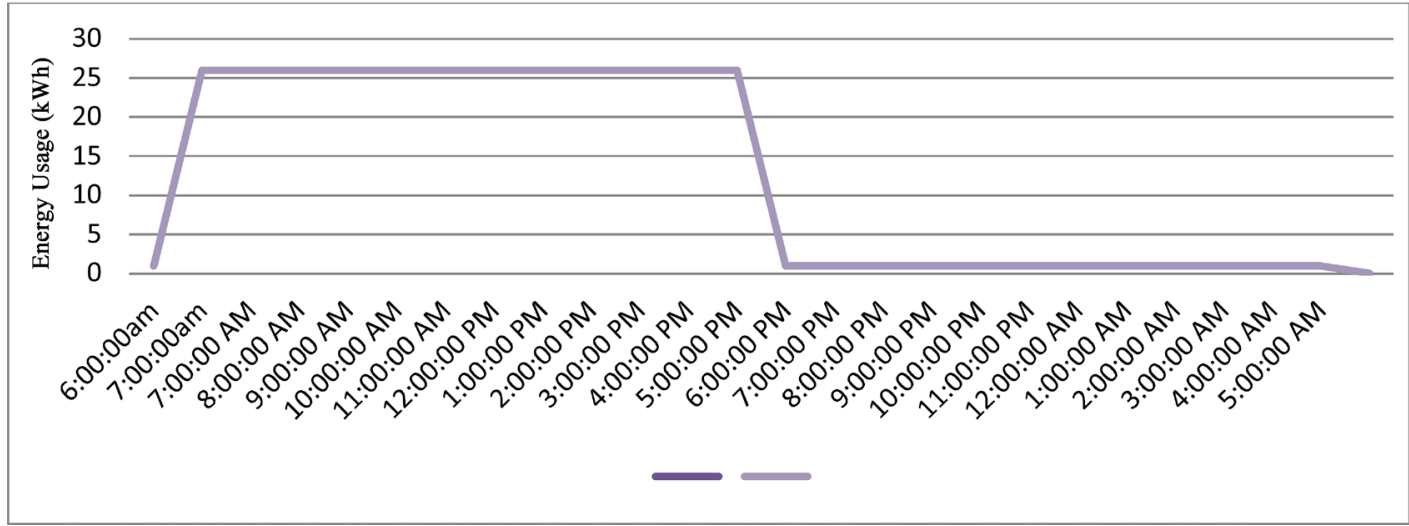

Figure 4. Energy use pattern for bank C.

storage system and inverter. Homer requires the capital costs, operating costs, maintenance costs, fuel costs and lifetime of the components to give a feasible hybrid system.

\subsubsection{Solar Panel}

The solar photovoltaic cells consist of Jinko mono-crystalline solar panels of 275 watts per panel. These solar panels have efficiency of up to $16.8 \%$. They have low light performance due to their surface texture that permits for excellent performance in low light environments. They also have severe weather resilience that can withstand wind and snow load. The cell temperature is given as $25^{\circ} \mathrm{C}$. The costs of installing the solar panels, solar racks, solar cables, and surge protectors amount to the project costs. Little maintenance is required for solar panels compared to diesel generators as the maintenance for solar panels mostly include cleaning of the photovoltaic cells. The life of the solar PV is given as 25 years and the derating factor is $88 \%$. Table 2 gives the detailed photovoltaic system input parameters.

\subsubsection{Diesel Generator}

Three diesel generators with sizes of $80 \mathrm{kVA}, 40 \mathrm{kVA}$ and $30 \mathrm{kVA}$ were evaluated. The diesel generators supply power to two banks and charge the batteries in the cycle charging operation. Lifetime is measured in hours and operation and maintenance costs are given in dollars per hour. The cost of diesel was taken to be $\$ 0.649$. The lifetime of the entire project was taken to be 25 years. Table 3 gives a description of the diesel generator input parameters.

\subsubsection{Inverter}

The inverters used in the three study areas were Sunny Tripower STP 15,000, 20,000 and 25,000 . The inverter has an efficiency of $98.1 \%$, maximum voltage of $1000 \mathrm{~V}$ and lifetime of 15 years. Table 4 shows the inverter capacity and costs for the three study areas.

\subsubsection{Battery}

The battery bank consists of Narada HTB-1000 batteries. Narada HTB-1000 has 
Table 2. Solar photovoltaic system input parameters.

\begin{tabular}{cccc}
\hline Description & Bank A & Bank B & Bank C \\
\hline Capacity (KW) & 35 & 30.3 & 25.3 \\
Capital costs (\$) & 14,240 & 11,298 & 10,905 \\
Replacement cost (\$) & 13,500 & 11,000 & 10,000 \\
Operation and maintenance cost (\$) & 20 & 11 & 10 \\
Efficiency (\%) & 16.8 & 16.8 & 16.8 \\
\hline
\end{tabular}

Table 3. Diesel generator input parameters.

\begin{tabular}{cccc}
\hline Description & Bank A & Bank B & Bank C \\
\hline Capacity (KW) & 32 & 24 & 64 \\
Capital Cost (\$) & 8972.3 & 8060.35 & $10,905.45$ \\
Replacement Cost (\$) & 8500 & 7500 & 10,500 \\
Operation and Maintenance Cost (\$/hr) & 1.14 & 0.51 & 4.2 \\
Lifetime (hrs) & 10,000 & 10,000 & 15,000 \\
\hline
\end{tabular}

Table 4. Inverter input parameter.

\begin{tabular}{cccc}
\hline Description & Bank A & Bank B & Bank C \\
\hline Capacity (KW) & 25 & 15 & 20 \\
Quantity & 1 & 2 & 1 \\
Capital Cost (\$) & 2549.55 & 4572 & 2935.65 \\
Replacement Cost (\$) & 2300 & 4565 & 2800 \\
\hline
\end{tabular}

Table 5. Battery input parameters.

\begin{tabular}{cccc}
\hline Battery & Bank A & Bank B & Bank C \\
\hline Capital Costs (\$) & 17,392 & $17,379.1$ & NO DATA \\
Replacement Cost (\$) & 17,000 & 17,000 & \\
Lifetime (yrs) & 15 & 15 & \\
Quantity & 24 & 24 & \\
\hline
\end{tabular}

a nominal voltage of $2 \mathrm{~V}$. The rated capacity is $100 \mathrm{Ah}$. The lifetime is 15 years and self discharge rate at $35^{\circ} \mathrm{C}$ of less than $5 \%$ per month. It has reduced maintenance as no water addition is required. The capital cost value of the battery include all costs associated with the battery bank project such as mounting hardware installation, labour and cost of a rack, room or building that houses the battery if possible. Table 5 contains the battery quantity and costs.

The input parameters were put into HOMER Pro software to carry out the performance evaluation of the hybrid systems with respect to the objective of this work. 


\section{Results and Discussion}

\subsection{Quantity of Emissions}

Emissions consists of six different gases with five having negligible quantities and Carbon dioxide making up the largest percentage among all the emissions released and as such was used to compare the quantity of emissions released. For Bank A, the diesel generator alone releases 111,618 kg/yr of Carbon dioxide while the hybrid system releases $41,618 \mathrm{~kg} / \mathrm{yr}$ of Carbon dioxide. The quantity of carbon dioxide emissions released from the diesel generator in Bank B was 53,830 $\mathrm{kg} / \mathrm{yr}$ while the carbon dioxide released from the hybrid energy system was 24,082 $\mathrm{kg} / \mathrm{yr}$. The diesel generator alone $177,799 \mathrm{~kg} / \mathrm{yr}$ of Carbon dioxide was released and $129,060 \mathrm{~kg} / \mathrm{yr}$ of carbon dioxide was released from the hybrid system for bank C. Therefore it is obvious that the diesel generator alone releases more emissions when compared with the hybrid system as observed in Table 6 .

Table 6. Carbon Dioxide Emissions from the Banks

\begin{tabular}{cccc}
\hline Source of Power & Bank A & Bank B & Bank C \\
\hline Diesel Generator alone & $111,618 \mathrm{~kg} / \mathrm{yr}$ & $53,830 \mathrm{~kg} / \mathrm{yr}$ & $177,799 \mathrm{~kg} / \mathrm{yr}$ \\
Hybrid System & $41,618 \mathrm{~kg} / \mathrm{yr}$ & $24,082 \mathrm{~kg} / \mathrm{yr}$ & $129,060 \mathrm{~kg} / \mathrm{yr}$ \\
\hline
\end{tabular}

\subsection{Economics of the Project}

\subsubsection{Bank A Diesel Generator}

The results from HOMER Pro show that the electricity production in a year is $122,285 \mathrm{kWh} / \mathrm{yr}$ with the cost of fuel consumed in a year $\$ 27,416$. The Levelized cost of energy is $\$ 0.713$ and net present cost is $\$ 644,391$. The total litre of fuel consumed in a year is $42,637 \mathrm{~L}$. The operation and maintenance cost is $\$ 9986$ per year.

\subsubsection{Bank A Hybrid System}

The results show that the yearly electricity production for the PV is 58,125 $\mathrm{kWh} / \mathrm{yr}$ while the electricity production in a year for the generator is 43,644 $\mathrm{kWh} / \mathrm{yr}$ giving a total of $101,769 \mathrm{kWh} / \mathrm{yr}$. The cost of fuel used in one year is $\$ 10,112$. The levelized cost of energy is $\$ 0.343$ while the net present cost is $\$ 310.019$. Fuel Consumption in one year is $15,726 \mathrm{~L}$. The operation and maintenance cost is $\$ 3957$ per year.

\subsubsection{Bank B Generator Alone}

The results show that the yearly electricity production in a year for the generator was $56,391 \mathrm{kWh} / \mathrm{yr}$. The cost of fuel used in one year is $\$ 13,880$. The levelized cost of energy is $\$ 0.568$ while the net present cost is $\$ 286,868$. The fuel consumption in one year is $20,567 \mathrm{~L}$ and the operation and maintenance cost is $\$ 3957$ per year.

\subsubsection{Bank B Hybrid System}

The results show that the yearly electricity production in a year for the generator 
was $22,791 \mathrm{kWh} / \mathrm{yr}$ and solar panel was $5428 \mathrm{kWh} / \mathrm{yr}$ giving a total of 34,345 $\mathrm{kWh} / \mathrm{yr}$. This was due to the smaller capacity of the generator and solar photovoltaic system compared to the systems in Banks A and C. The cost of fuel used in one year was $\$ 5777$. The levelized cost of energy is $\$ 0.2553$ while the net present cost was $\$ 130,116$. The fuel consumption in one year was $8558 \mathrm{~L}$. The operation and maintenance cost was $\$ 1450$ per year.

\subsubsection{Bank C Diesel Generator Alone}

The results show that the yearly electricity production in a year was 206,605 $\mathrm{kWh} / \mathrm{yr}$ due to the large capacity of the diesel generator. The cost of fuel used in one year was $\$ 5777$. The levelized cost of energy was $\$ 0.731$ while the net present cost was $\$ 1.15 \mathrm{M}$. The fuel consumption in one year was $67,969 \mathrm{~L}$. The operation and maintenance cost was $\$ 36,792$ per year.

\subsubsection{Bank C Hybrid System}

The electricity Production for the diesel generator is $147,093 \mathrm{kWh} / \mathrm{yr}$. The electricity production for the solar photovoltaic system alone is $45,324 \mathrm{kWh} / \mathrm{yr}$. The cost of Fuel was $\$ 34,045$. The levelized cost of energy is $\$ 0.566$ and net present cost is $\$ 891,160$. The fuel consumption per year was 49,3431 and the operation and maintenance cost was $\$ 28,462$ per year.

\section{Conclusion}

In this work, an investigative study on emissions and cost analysis of solar PVdiesel hybrid system was carried out and compared with that of diesel powered stand-alone system. The study revealed that the unit cost of energy of diesel system is more than that of the installed hybrid system. Net present cost of the hybrid system is also less than that of the diesel powered generating system even with the high initial costs of installing the photovoltaic system. It can be implied from the study that renewable energy based hybrid power system diminishes the emission of carbon dioxide which is a major greenhouse gas. Therefore, renewable energy based hybrid power is considered as one of the most environmental friendly and economical solutions for providing reliable electricity to locations that are isolated from the national grid as well as those on national grid but facing the challenge of epileptic power supply.

\section{Conflicts of Interest}

The authors declare no conflicts of interest regarding the publication of this paper.

\section{References}

[1] Alam, M.S. (2006) Economic Growth with Energy. MPRA Paper 1260. University Library of Munich, Munich.

[2] Oseni, M.O. (2012) Improving Households Access to Electricity and Energy Consumption Pattern in Nigeria: Renewable Energy Alternative. Renewable and Sustainable Energy Reviews, 16, 3967-3974. https://doi.org/10.1016/j.rser.2012.03.010 
[3] Gbadebo, O. and Okonkwo, C. (2009) Does Energy Consumption Contribute to Economic Performance? Empirical Evidence from Nigeria. Journal of Economics and International Finance, 2, 44-58.

[4] Joy, N. (2017) Evaluating the Impact of Power Pool in Selected West African Countries for Enhanced Power Supply. Ph.D. Dissertation, Michael Okpara University of Agriculture, Umudike.

[5] U.S. Energy Information Administration (2013) International Energy Outlook 2013 with Projections to 2040. Washington DC.

[6] Owusu, P.A. and Asumadu-Sarkodie, S. (2016) A Review of Renewable Energy Sources, Sustainability Issues and Climate Change Mitigation. Cogent Engineering, 3, Article ID: 1167990. https://doi.org/10.1080/23311916.2016.1167990

[7] Oviroh, P.O. and Jen, T. (2018) The Energy Cost Analysis of Hybrid Systems and Diesel Generators in Powering Selected Base Transceiver Station Locations in Nigeria. Energies, 11, 687. https://doi.org/10.3390/en11030687

[8] Alqurashi, A. (2021) Economic and Environmental Impacts of Distributed Energy Resources. Journal of Clean Energy Technologies, 9, 28-32.

[9] Vallejo, L., Mazu, C., Strapasson, A., Cockerill, T., Gambhir, A., Hills, T., Jennings, M., Jones, O., Kalas, N., Keirstead, J., Khor, C., Napp, T., Tong, D., Woods, J. and Shah, N. (2021) Halving Global $\mathrm{CO}_{2}$ Emissions by 2050: Technologies and Costs. International Energy Journal, 21, 147-158.

[10] Buonocore, J.J., Hughes, E.J. Michanowicz, D.R., Heo, J., Allen, J.G. and Williams, A. (2019) Climate and Health Benefits of Increasing Renewable Energy Deployment in the United States. Environmental Research Letters, 14, Article ID: 114010. https://doi.org/10.1088/1748-9326/ab49bc

[11] Martins, F., Felgueiras, C., Smitkova, M. and Caetano, N. (2019) Analysis of Fossil Fuel Energy Consumption and Environmental Impacts in European Countries. Energies, 12, 964. https://doi.org/10.3390/en12060964

[12] Palatel, A. (2017) Isolated Hybrid Energy Systems for Remote Locations. Encyclopedia of Sustainable Technologies, 2017, 205-216. https://doi.org/10.1016/B978-0-12-409548-9.10145-9

[13] Manwell, J.F. (2004) Hybrid Energy Systems. Encyclopedia of Energy, 2004, 215-229. https://doi.org/10.1016/B0-12-176480-X/00360-0

[14] Peterson, T.C, Gallo, K.P., Lawrimore, J., Owen, T.W, Huang, A. and McKittrick, D.A. (1999) Global Rural Temperature Trends. Geophysical Research Letters, 26, 329332.https://doi.org/10.1029/1998GL900322

[15] Adejuyigbe, S.B., Bolaji, B.O., Olanipekun, M.U. and Adu, M.R. (2012) Development of a Solar Photovoltaic Power System to Generate Electricity for Office Appliances. Engineering Journal, 17, 29-39. https://doi.org/10.4186/ej.2013.17.1.29

[16] Bolaji, B.O. and Adu, M.R. (2007) Design Analysis of Photovoltaic Pumping System for Rural Application in Nigeria. ASSET Series B, 6, 120-130.

[17] Kartite, J. and Cherkaoui, M. (2019) Study of the Different Structures of Hybrid Systems in Renewable Energies: A Review. Energy Procedia, 157, 323-330.

https://doi.org/10.1016/j.egypro.2018.11.197

[18] Khare, A and Rangnekar, S. (2013) Optimal Sizing an SPV/Diesel/Battery Hybrid System for a Remote Railway Station in India. International Journal of Renewable Energy Research, 3, 673-681.

[19] Kamel, S.M. and Dahl, C. (2005) The Economics of Hybrid Power Systems for Sustainable Desert Agriculture in Egypt. Energy, 30, 1271-1281. 
https://doi.org/10.1016/j.energy.2004.02.004

[20] Nafeh, A.A. (2011) Optimal Economical Sizing of a PV-Wind Hybrid Energy System Using Genetic Algorithm. International Journal of Green Energy, 8, 25-43. https://doi.org/10.1080/15435075.2010.529407 